\title{
Synthesis, Characterization, Crystal Structures, and Urease Inhibition of Copper(II) and Zinc(II) Complexes Derived from Benzohydrazones
}

\author{
Fu-Ming Wang, ${ }^{1,}{ }^{*}$ Li-Jie Li, ${ }^{2}$ Guo-Wei Zang, ${ }^{2}$ Tong-Tong Deng ${ }^{2}$ \\ and Zhong-Lu You ${ }^{3}$ \\ ${ }^{1}$ Key Laboratory of Coordination Chemistry and Functional Materials in Universities of Shandong, \\ Department of Chemistry, Dezhou University, Dezhou 253023, P. R. China \\ ${ }^{2}$ School of Chemistry and Chemical Engineering, Beijing Institute of Technology, Beijing 100081, P. R. China \\ ${ }^{3}$ Department of Chemistry and Chemical Engineering, Liaoning Normal University, Dalian 116029, P. R. China \\ * Corresponding author: E-mail:wfm99999@126.com
}

Received: 04-24-2020

\begin{abstract}
A new copper(II) complex $\left[\mathrm{Cu}\left(\mathrm{L}^{1}\right)(\mathrm{NCS})\left(\mathrm{CH}_{3} \mathrm{OH}\right)\right](\mathbf{1})$ and a new zinc(II) complex $\left[\mathrm{ZnCl}_{2}\left(\mathrm{HL}^{2}\right)\right] \cdot \mathrm{CH}_{3} \mathrm{OH}(\mathbf{2})$, derived from 4-bromo- $N^{\prime}$-(pyridin-2-ylmethylene)benzohydrazide $\left(\mathrm{HL}^{1}\right)$ and 4-methoxy- $N^{\prime}$-(pyridin-2-ylmethylene)benzohydrazide $\left(\mathrm{HL}^{2}\right)$, were prepared and characterized by elemental analysis, IR and UV-Vis spectroscopy and single crystal $\mathrm{X}$-ray diffraction. The hydrazone $\mathrm{HL}^{1}$ coordinates to the $\mathrm{Cu}$ atom in enolate form, while the hydrazone $\mathrm{HL}^{2}$ coordinates to the $\mathrm{Zn}$ atom in carbonyl form. Single crystal structural analyses indicate that the hydrazones coordinate to the metal atoms through the pyridine $\mathrm{N}$, imino $\mathrm{N}$, and enolate/carbonyl $\mathrm{O}$ atoms. The $\mathrm{Cu}$ atom in complex $\mathbf{1}$ is in square pyramidal coordination, and the $\mathrm{Zn}$ atom in complex $\mathbf{2}$ is in trigonal-bipyramidal coordination. The inhibitory effects of the complexes on Jack bean urease were studied, which show that the copper complex has strong activity on urease.
\end{abstract}

Keywords: Hydrazone; copper complex; zinc complex; crystal structure; urease inhibition

\section{Introduction}

Urease (EC 3.5.1.5; urea amidohydrolase) is a binuclear nickel-dependent hydrolase enzyme, which can be synthesized by numerous organisms, including plants, bacteria, algae, fungi, and invertebrates, and occurs widely in animal and soil. ${ }^{1}$ Urease enzyme catalyzes the decomposition of urea into ammonia and carbon dioxide in high efficiency, ${ }^{2}$ with the rate of catalyzed reaction $10^{14}$ times higher than the non-catalyzed reaction. ${ }^{3}$ The enzyme possesses harmful effects on both human health and fertile soil. ${ }^{4}$ In recent years, Schiff base complexes are reported to have interesting urease inhibitory activities, ${ }^{5}$ especially the copper complexes with Schiff bases or hydrazones are promising types of lead structures as urease inhibitors. ${ }^{6}$ As a continuation of the work on the exploration of new urease inhibitors, a new copper(II) complex $\left[\mathrm{Cu}\left(\mathrm{L}^{1}\right)(\mathrm{NCS})\right.$ $\left.\left(\mathrm{CH}_{3} \mathrm{OH}\right)\right](\mathbf{1})$ and a new zinc(II) complex $\left[\mathrm{ZnCl}_{2}\left(\mathrm{HL}^{2}\right)\right]$. $\mathrm{CH}_{3} \mathrm{OH}$ (2), derived from 4-bromo- $N$ '-(pyridin-2-yl-

methylene)benzohydrazide $\left(\mathrm{HL}^{1}\right)$ and 4-methoxy- $N^{\prime}$-(pyridin-2-ylmethylene)benzohydrazide ( $\mathrm{HL}^{2}$; Scheme 1), were prepared and studied on their urease inhibition activity.<smiles>O=C(N/N=C/c1ccccn1)c1ccc(Br)cc1</smiles>

Scheme 1. $\mathrm{HL}^{1}$ and $\mathrm{HL}^{2}$

\section{Experimental}

\section{1. Materials and Measurements}

All reagents and solvents were of commercially available reagent grade quality and were used without further purification. $\mathrm{HL}^{1}$ was synthesized according to the literature method. ${ }^{7}$ Jack bean urease was purchased from Sig- 
ma-Aldrich. Elemental analyses were performed on a Perkin-Elmer 240C elemental analyzer. IR spectra were recorded on a Jasco FT/IR-4000 spectrometer as $\mathrm{KBr}$ pellets in the $4000-400 \mathrm{~cm}^{-1}$ region. UV-Vis spectra were recorded on a Perkin-Elmer Lambda 900 spectrometer. ${ }^{1} \mathrm{H}$ NMR and ${ }^{13} \mathrm{C}$ NMR spectra were recorded on a $500 \mathrm{MHz}$ Bruker Advance instrument. The urease inhibitory activity was measured on a Bio-Tek Synergy HT microplate reader. Single crystal structures were determined by Bruker Smart 1000 CCD area diffraction.

\section{2. Synthesis of $\mathrm{HL}^{2}$}

2-Pyridinecarboxaldehyde $(0.01 \mathrm{~mol}, 1.07 \mathrm{~g})$ and 4-methoxybenzohydrazide $(0.01 \mathrm{~mol}, 1.66 \mathrm{~g})$ were dissolved in methanol $(100 \mathrm{~mL})$. The mixture was stirred at reflux for $1 \mathrm{~h}$ and the solvent removed by distillation at reduced pressure. The solid product was re-crystallized from methanol to give colorless crystals. Yield: $1.72 \mathrm{~g}$ (68\%). Characteristic IR data $\left(\mathrm{KBr}, \mathrm{cm}^{-1}\right): 3227(\mathrm{NH})$, $1645(\mathrm{C}=\mathrm{O}), 1607(\mathrm{C}=\mathrm{N})$. UV-Vis data (methanol, $\lambda / \mathrm{nm})$ : 305, 370. Anal. Calcd for $\mathrm{C}_{14} \mathrm{H}_{13} \mathrm{~N}_{3} \mathrm{O}_{2}$ : C, 65.87; $\mathrm{H}, 5.13 ; \mathrm{N}$, 16.46. Found: C, 65.71; H, 5.25; N, 16.32\%. ${ }^{1} \mathrm{H}$ NMR (DMSO- $\left.d_{6}, 500 \mathrm{MHz}\right) \delta(\mathrm{ppm}): 11.96(\mathrm{~s}, 1 \mathrm{H}, \mathrm{NH}), 8.62(\mathrm{~d}, 1 \mathrm{H}$, $\mathrm{PyH}), 8.47$ (s, $1 \mathrm{H}, \mathrm{CH}=\mathrm{N}), 7.99-7.89(\mathrm{~m}, 4 \mathrm{H}, \mathrm{Py} H+\mathrm{Ar} H)$, $7.42(\mathrm{q}, 1 \mathrm{H}, \mathrm{PyH}), 7.10(\mathrm{~d}, 2 \mathrm{H}, \mathrm{ArH}), 3.84\left(\mathrm{~s}, 3 \mathrm{H}, \mathrm{CH}_{3}\right) \cdot{ }^{13} \mathrm{C}$ NMR (DMSO- $\left.d_{6}, 126 \mathrm{MHz}\right) \delta$ (ppm): $162.70,162.11$, $153.37,149.43,147.36,136.76,129.62,125.16,124.19$, $119.74,113.71,55.40$.

\section{3. Synthesis of the Complex 1}

$\mathrm{HL}^{1}(1.0 \mathrm{mmol}, 0.30 \mathrm{~g})$ was dissolved in methanol $(20 \mathrm{~mL})$, to which $\mathrm{Cu}\left(\mathrm{ClO}_{4}\right)_{2} \cdot 6 \mathrm{H}_{2} \mathrm{O}(1.0 \mathrm{mmol}, 0.37 \mathrm{~g})$ and ammonium thiocyanate $(1.0 \mathrm{mmol}, 0.076 \mathrm{~g})$ dissolved in methanol $(20 \mathrm{~mL})$ were added dropwise. The mixture was stirred for $10 \mathrm{~min}$ at room temperature and filtered. The filtrate was kept in air for a few days, to form crystals suitable for single crystal X-ray diffraction. The crystals were isolated by filtration. Yield: $0.18 \mathrm{~g}(39 \%)$. Characteristic IR data $\left(\mathrm{KBr}, \mathrm{cm}^{-1}\right): 3450(\mathrm{OH}), 2043$ (NCS), 1602 $(\mathrm{CH}=\mathrm{N}), 1447,1372,1161,1070,952,860,535 . \mathrm{UV}-\mathrm{Vis}$ data (methanol, $\lambda / \mathrm{nm}$ ): 270, 370. Anal. Calcd for $\mathrm{C}_{15} \mathrm{H}_{13}$ $\mathrm{BrCuN}_{4} \mathrm{O}_{2} \mathrm{~S}: \mathrm{C}, 39.44 ; \mathrm{H}, 2.87 ; \mathrm{N}, 12.26$. Found: C, 39.27; $\mathrm{H}, 2.98 ; \mathrm{N}, 12.41 \%$.

\section{4. Synthesis of the Complex 2}

$\mathrm{HL}^{2}$ (1.0 mmol, $0.26 \mathrm{~g}$ ) was dissolved in methanol $(20 \mathrm{~mL})$, to which $\mathrm{ZnCl}_{2}(1.0 \mathrm{mmol}, 0.14 \mathrm{~g})$ dissolved in methanol $(20 \mathrm{~mL})$ was added dropwise. The mixture was stirred for $10 \mathrm{~min}$ at room temperature and filtered. The filtrate was kept in air for a few days, to form crystals suitable for single crystal X-ray diffraction. The crystals were isolated by filtration. Yield: $0.26 \mathrm{~g}(61 \%)$. Characteristic IR data $\left(\mathrm{KBr}, \mathrm{cm}^{-1}\right): 3463(\mathrm{OH}), 1672(\mathrm{C}=\mathrm{O}), 1604(\mathrm{CH}=\mathrm{N})$, $1455,1369,1276,1158,1078,947,860,544,520$. UV-Vis data (methanol, $\lambda / \mathrm{nm}$ ): 305,380 . Anal. Calcd for $\mathrm{C}_{15} \mathrm{H}_{17}$ $\mathrm{Cl}_{2} \mathrm{~N}_{3} \mathrm{O}_{3} \mathrm{Zn}: \mathrm{C}, 42.53 ; \mathrm{H}, 4.05 ; \mathrm{N}, 9.92$. Found: C, $42.71 ; \mathrm{H}$, $4.13 ; \mathrm{N}, 9.80 \%$.

Table 1. Crystallographic and experimental data for the compounds

\begin{tabular}{lccc}
\hline Compound & $\mathbf{H L}^{2}$ & $\mathbf{1}$ & $\mathbf{2}$ \\
\hline Formula & $\mathrm{C}_{14} \mathrm{H}_{15} \mathrm{~N}_{3} \mathrm{O}_{3}$ & $\mathrm{C}_{15} \mathrm{H}_{13} \mathrm{BrCuN}_{4} \mathrm{O}_{2} \mathrm{~S}$ & $\mathrm{C}_{15} \mathrm{H}_{17} \mathrm{Cl}_{2} \mathrm{~N}_{3} \mathrm{O}_{3} \mathrm{Zn}$ \\
$M_{\mathrm{r}}$ & 273.3 & 456.8 & 423.6 \\
Crystal system & Triclinic & Monoclinic & Triclinic \\
Space group & $P \overline{1}$ & $P{ }_{1} / n$ & $P \overline{1}$ \\
$a(\AA)$ & $6.6036(12)$ & $7.3009(5)$ & $7.8943(4)$ \\
$b(\AA)$ & $14.6112(11)$ & $17.3938(13)$ & $8.3352(5)$ \\
$c(\AA)$ & $15.2091(13)$ & $13.7578(10)$ & $14.7609(9)$ \\
$\alpha\left({ }^{\circ}\right)$ & $71.232(2)$ & 90 & $104.246(1)$ \\
$\beta\left({ }^{\circ}\right)$ & $84.436(2)$ & $96.629(1)$ & $100.125(1)$ \\
$\gamma\left({ }^{\circ}\right)$ & $84.520(2)$ & 90 & $99.016(1)$ \\
$V\left(\AA^{3}\right)$ & $1379.7(3)$ & $1735.4(2)$ & $906.16(9)$ \\
$Z$ & 4 & 4 & 2 \\
$D_{c}(\mathrm{~g}$ cm & -3 \\
$\mu\left(\right.$ Mo-Ka) $\left(\mathrm{mm}^{-1}\right)$ & 1.316 & 1.748 & 1.552 \\
$F(000)$ & 0.095 & 3.696 & 1.668 \\
Reflections collected & 576 & 908 & 432 \\
Unique reflections & 8135 & 8964 & 4869 \\
Observed reflections $(I \geq 2 \sigma(I))$ & 5104 & 3218 & 3345 \\
Parameters & 3655 & 2514 & 2995 \\
Restraints & 381 & 221 & 231 \\
Goodness-of-fit on $F^{2}$ & 6 & 1 & 2 \\
$R_{1}, w R_{2}[I \geq 2 \sigma(I)]$ & 1.041 & 1.039 & 1.060 \\
$R_{1}, w R_{2}($ all data) & $0.0535,0.1425$ & $0.0381,0.0891$ & $0.0256,0.0658$ \\
Large diff. peak and hole $\left(\mathrm{e} \AA^{-3}\right)$ & $0.0775,0.1609$ & $0.0545,0.0959$ & $0.0301,0.0681$ \\
\hline & $0.223,-0.249$ & $0.977,-0.471$ & $0.274,-0.234$ \\
\hline
\end{tabular}




\section{5. X-Ray Crystallography}

Diffraction intensities for $\mathrm{HL}^{2}$ and the complexes were collected at 298(2) K using a Bruker Smart 1000 CCD area diffractometer with $\operatorname{MoK} \alpha$ radiation $(\lambda=0.71073 \AA)$. The collected data were reduced with SAINT, ${ }^{8}$ and multiscan absorption correction was performed using SADABS. ${ }^{9}$ Structures of $\mathrm{HL}^{2}$ and the complexes were solved by direct methods and refined against $F^{2}$ by full-matrix leastsquares method using SHELXTL. ${ }^{10}$ All of the non-hydrogen atoms were refined anisotropically. The amino and methanol $\mathrm{H}$ atoms in the compounds were located from difference Fourier maps and refined isotropically, with $\mathrm{N}-\mathrm{H}$ and $\mathrm{O}-\mathrm{H}$ distances restrained to $0.90(1)$ and $0.85(1)$ $\AA$, respectively. The remaining hydrogen atoms were placed in calculated positions and constrained to ride on their parent atoms. Crystallographic data for $\mathrm{HL}^{2}$ and the complexes are summarized in Table 1. Selected bond lengths and angles are given in Table 2.

\section{6. Urease Inhibitory Activity Assay}

The measurement of urease inhibitory activity was carried out according to the literature method. ${ }^{11}$ The assay mixture containing $75 \mu \mathrm{L}$ of Jack bean urease and $75 \mu \mathrm{L}$ of tested compounds with various concentrations (dissolved in DMSO) was pre-incubated for 15 min on a 96-well assay plate. Acetohydroxamic acid was used as a reference. Then $75 \mu \mathrm{L}$ of phosphate buffer at $\mathrm{pH} 6.8$ containing phenol red $\left(0.18 \mathrm{mmol} \mathrm{L}^{-1}\right)$ and urea $\left(400 \mathrm{mmol} \mathrm{L}^{-1}\right)$ were added and incubated at room temperature. The reaction time required
Table 2. Selected bond lengths $/ \AA$ and angles $/{ }^{\circ}$ for the compounds

\begin{tabular}{|c|c|c|c|}
\hline \multicolumn{4}{|l|}{$\mathrm{HL}^{2}$} \\
\hline C6-N2 & $1.272(3)$ & $\mathrm{N} 2-\mathrm{N} 3$ & $1.375(2)$ \\
\hline N3-C7 & $1.356(3)$ & $\mathrm{C} 7-\mathrm{O} 1$ & $1.229(3)$ \\
\hline C20-N5 & $1.273(3)$ & N5-N6 & $1.369(2)$ \\
\hline N6-C21 & $1.360(3)$ & $\mathrm{C} 21-\mathrm{O} 3$ & $1.229(2)$ \\
\hline C6-N2-N3 & $116.4(2)$ & $\mathrm{N} 2-\mathrm{N} 3-\mathrm{C} 7$ & $118.6(2)$ \\
\hline C20-N5-N6 & $116.9(2)$ & N5-N6-C21 & $118.1(2)$ \\
\hline \multicolumn{4}{|l|}{1} \\
\hline $\mathrm{Cu} 1-\mathrm{N} 1$ & $2.007(3)$ & $\mathrm{Cu} 1-\mathrm{N} 2$ & $1.928(3)$ \\
\hline $\mathrm{Cu} 1-\mathrm{O} 1$ & $1.965(3)$ & $\mathrm{Cu} 1-\mathrm{O} 2$ & $2.284(4)$ \\
\hline $\mathrm{Cu} 1-\mathrm{N} 4$ & $1.927(4)$ & & \\
\hline C6-N2 & $1.280(4)$ & $\mathrm{N} 2-\mathrm{N} 3$ & $1.375(4)$ \\
\hline $\mathrm{N} 3-\mathrm{C} 7$ & $1.333(4)$ & $\mathrm{C} 7-\mathrm{O} 1$ & $1.277(5)$ \\
\hline N4-Cu1-N2 & 159.33(18) & $\mathrm{N} 4-\mathrm{Cu} 1-\mathrm{O} 1$ & $99.50(14)$ \\
\hline N2-Cu1-O1 & $79.18(12)$ & N4-Cu1-N1 & $97.74(15)$ \\
\hline N2-Cu1-N1 & $80.75(12)$ & $\mathrm{O} 1-\mathrm{Cu} 1-\mathrm{N} 1$ & $159.48(13)$ \\
\hline N4-Cu1-O2 & $111.53(19)$ & $\mathrm{N} 2-\mathrm{Cu} 1-\mathrm{O} 2$ & $89.14(13)$ \\
\hline $\mathrm{O} 1-\mathrm{Cu} 1-\mathrm{O} 2$ & $90.15(14)$ & $\mathrm{N} 1-\mathrm{Cu} 1-\mathrm{O} 2$ & $93.81(15)$ \\
\hline C6-N2-N3 & $124.4(3)$ & N2-N3-C7 & 107.2(3) \\
\hline \multicolumn{4}{|l|}{2} \\
\hline Zn1-N1 & $2.1462(16)$ & $\mathrm{Zn} 1-\mathrm{N} 2$ & $2.1149(16)$ \\
\hline $\mathrm{Zn} 1-\mathrm{Cl} 1$ & $2.2233(6)$ & $\mathrm{Zn} 1-\mathrm{Cl} 2$ & $2.2348(6)$ \\
\hline $\mathrm{Zn} 1-\mathrm{O} 1$ & $2.2979(14)$ & & \\
\hline $\mathrm{N} 2-\mathrm{Zn} 1-\mathrm{N} 1$ & $74.91(6)$ & $\mathrm{N} 2-\mathrm{Zn} 1-\mathrm{Cl} 1$ & $115.82(5)$ \\
\hline N1-Zn1-Cl1 & $101.84(5)$ & $\mathrm{N} 2-\mathrm{Zn} 1-\mathrm{Cl} 2$ & $124.21(5)$ \\
\hline $\mathrm{N} 1-\mathrm{Zn} 1-\mathrm{Cl} 2$ & $103.10(5)$ & $\mathrm{Cl} 1-\mathrm{Zn} 1-\mathrm{Cl} 2$ & $118.93(3)$ \\
\hline N2-Zn1-O1 & $70.54(5)$ & $\mathrm{N} 1-\mathrm{Zn} 1-\mathrm{O} 1$ & $145.28(6)$ \\
\hline $\mathrm{Cl1}-\mathrm{Zn} 1-\mathrm{O} 1$ & $96.04(5)$ & $\mathrm{Cl} 2-\mathrm{Zn} 1-\mathrm{O} 1$ & $93.65(4)$ \\
\hline
\end{tabular}<smiles>[X]c1ccc(C(=O)NN=Cc2ccccn2)cc1</smiles>

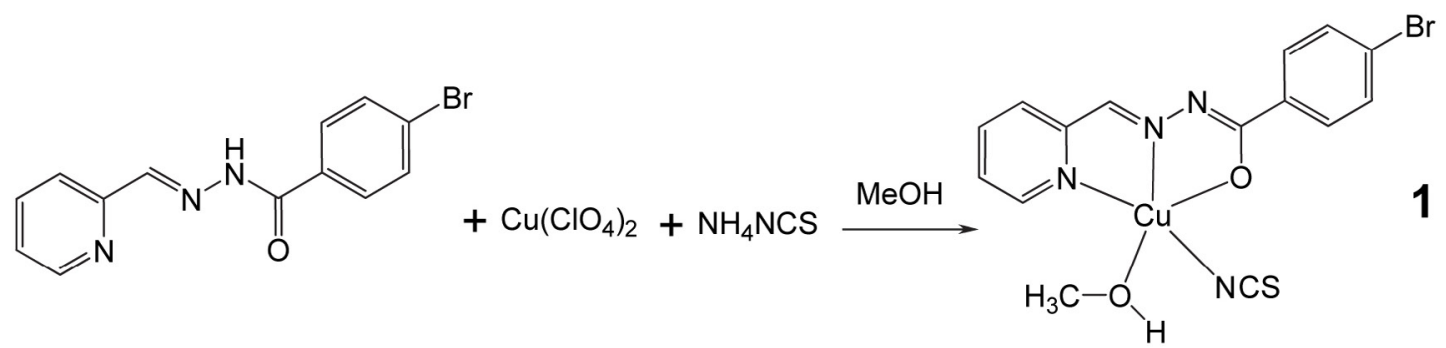<smiles>COc1ccc(C(=O)N/N=C/c2ccccn2)cc1</smiles>

Scheme 2. The synthetic procedure of the hydrazones and the complexes. $\mathrm{X}=\mathrm{Br}$ for $\mathrm{HL}^{1}, \mathrm{OMe}$ for $\mathrm{HL}^{2}$. 
for enough ammonium carbonate to form to raise the $\mathrm{pH}$ phosphate buffer from 6.8 to 7.7 was measured by micro-plate reader $(560 \mathrm{~nm})$ with end-point being determined by the color change of phenol-red indicator.

\section{Results and Discussion}

\section{1. Chemistry}

The synthetic procedure of the hydrazones and the complexes is shown in Scheme 2. The hydrazone $\mathrm{HL}^{2}$ was prepared by the condensation reaction of equimolar quantities of 2-pyridinecarboxaldehyde and 4-methoxybenzohydrazide. The copper complex was prepared by reaction of equimolar quantities of $\mathrm{HL}^{1}$, copper perchlorate, and ammonium thiocyanate in methanol. The zinc complex was prepared by reaction of equimolar quantities of $\mathrm{HL}^{2}$ and zinc chloride in methanol. Single crystals of $\mathrm{HL}^{2}$ and the complexes were obtained by slow evaporation of the methanolic solution of the compounds.

\section{2. Structure Description of $\mathbf{H L}^{2}$}

The molecular structure of $\mathrm{HL}^{2}$ is shown in Figure 1. The compound contains two hydrazone molecules and two water molecules of crystallization. The hydrazone molecules adopt $E$ configuration with respect to the methylidene unit. The distances of the methylidene bonds confirm them as typical double bonds. The shorter distances of the $\mathrm{C}-\mathrm{N}$ bonds and the longer distances of the $\mathrm{C}=\mathrm{O}$ bonds for the $-\mathrm{C}(\mathrm{O})-\mathrm{NH}-$ units than usual, suggests the presence of conjugation effects in the hydrazone molecules. The remaining bond lengths in the compounds are within normal values. ${ }^{12}$ The dihedral angles between the pyridine and benzene rings are $61.0(3)^{\circ}$ for one molecule and $18.4(3)^{\circ}$ for the other one. The hydrazone molecules are linked by water molecules through hydrogen bonds of $\mathrm{O}-\mathrm{H} \cdots \mathrm{O}$ and $\mathrm{O}-\mathrm{H} \cdots \mathrm{N}$ (Table 3, and Figure 2).

\section{3. Structure Description of the Copper Complex}

Molecular structure of the copper complex is shown in Figure 3. The $\mathrm{Cu}$ atom is in square pyramidal geometry, with the pyridine $\mathrm{N}$, imino $\mathrm{N}$, and enolate $\mathrm{O}$ atoms of the hydrazone ligand, and the thiocyanato $\mathrm{N}$ atom located at the basal plane, and with the methanol $\mathrm{O}$ atom located at the apical position. The $\mathrm{Cu}$ atom deviates from the leastsquares plane defined by the four basal donor atoms by $0.242(1) \AA$. The coordinate bond lengths in the complex

Table 3. Hydrogen bond distances $(\AA)$ and bond angles $\left(^{\circ}\right)$ for the compounds

\begin{tabular}{|c|c|c|c|c|}
\hline$D-\mathrm{H} \cdots A$ & $d(D-\mathbf{H})$ & $d(\mathrm{H} \cdots A)$ & $d(\mathrm{D} \cdots A)$ & Angle $(D-\mathrm{H} \cdots A)$ \\
\hline \multicolumn{5}{|l|}{$\mathrm{HL}^{2}$} \\
\hline O5-H5B $\cdots \mathrm{N} 1$ & $0.85(1)$ & $2.18(2)$ & $2.982(3)$ & $157(2)$ \\
\hline $\mathrm{O} 5-\mathrm{H} 5 \mathrm{~A} \cdots \mathrm{O} 3$ & $0.85(1)$ & $1.99(1)$ & $2.808(2)$ & $162(3)$ \\
\hline O6-H6B $\cdots O 1^{\mathrm{i}}$ & $0.85(1)$ & $1.99(1)$ & $2.830(3)$ & $165(3)$ \\
\hline O6-H6A $\cdots 4^{i}$ & $0.85(1)$ & $2.19(2)$ & $2.981(3)$ & $155(3)$ \\
\hline N3-H3 ‥O6 & 0.86 & 2.04 & $2.863(3)$ & $161(3)$ \\
\hline N6-H6C $\cdots O 5^{\mathrm{ii}}$ & 0.86 & 2.07 & $2.898(2)$ & $162(3)$ \\
\hline \multicolumn{5}{|l|}{1} \\
\hline $\mathrm{O} 2-\mathrm{H} 2 \cdots \mathrm{N} 3^{\mathrm{iii}}$ & $0.85(1)$ & $1.99(2)$ & $2.840(4)$ & $171(4)$ \\
\hline \multicolumn{5}{|l|}{2} \\
\hline $\mathrm{O} 3-\mathrm{H} 3 \mathrm{~B} \cdots \mathrm{O} 1^{\mathrm{i}}$ & 0.82 & 2.26 & $2.997(2)$ & $149(3)$ \\
\hline $\mathrm{N} 3-\mathrm{H} 3 \cdots \mathrm{O} 3$ & $0.89(1)$ & $1.93(1)$ & $2.785(2)$ & $161(3)$ \\
\hline
\end{tabular}

Symmetry codes: (i) $-1+x, y, z$; (ii) $1+x, y, z$; (iii) $-x,-y+2,-z+2$.

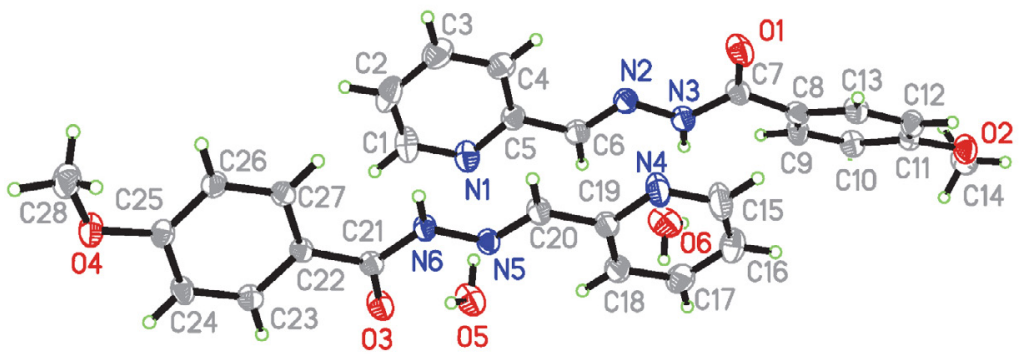

Figure 1. Molecular structure of $\mathrm{HL}^{2}$, showing the atom-numbering scheme. Displacement ellipsoids for non-hydrogen atoms are drawn at $30 \%$ probability level. 


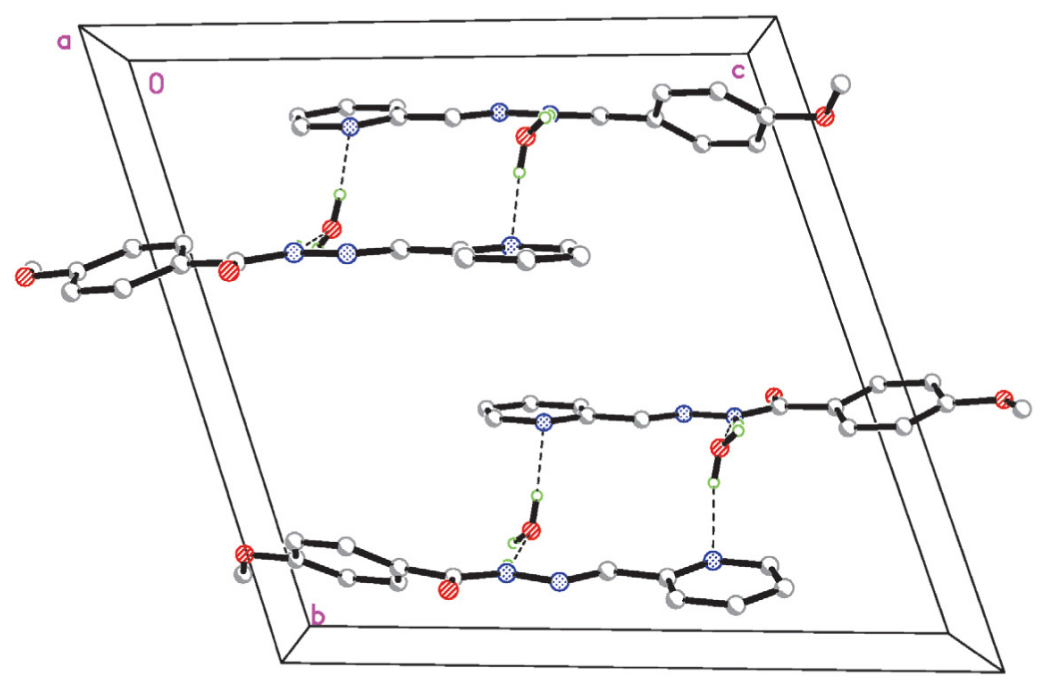

Figure 2. Molecular packing structure of HL, viewed along the $a$ axis. Hydrogen bonds are shown as dashed lines.

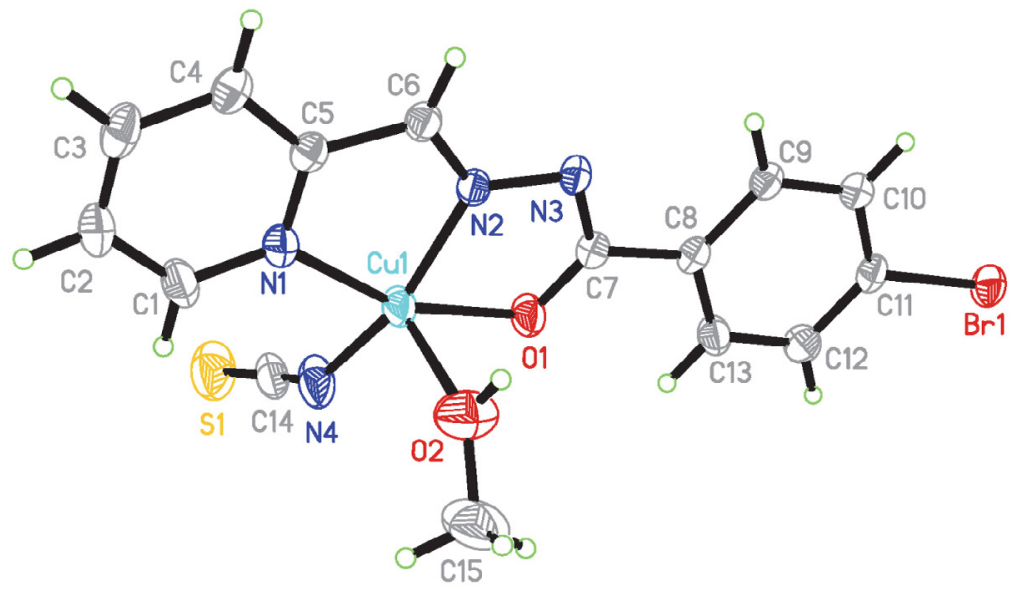

Figure 3. Molecular structure of $\mathbf{1}$, showing the atom-numbering scheme. Displacement ellipsoids for non-hydrogen atoms are drawn at $30 \%$ probability level.

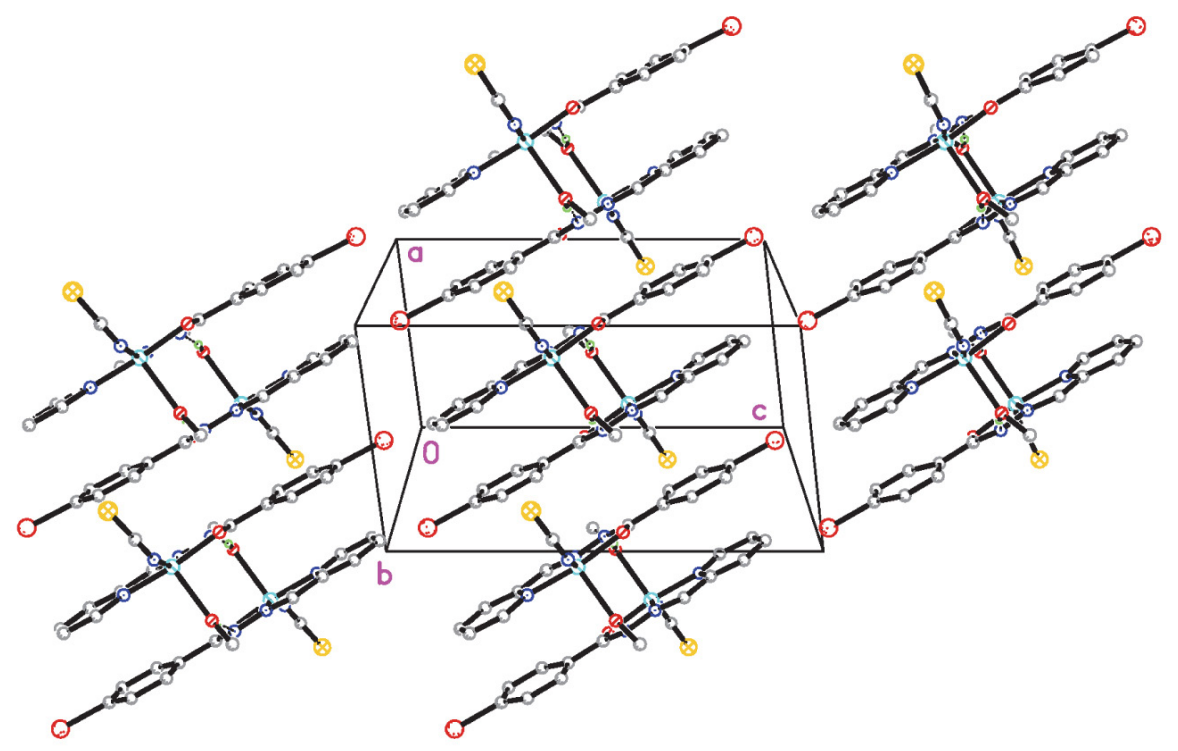

Figure 4. Molecular packing structure of $\mathbf{1}$, viewed along the $b$ axis. Hydrogen bonds are shown as dashed lines. 
are comparable to those observed in copper(II) complexes with hydrazone ligands. ${ }^{6 a, 13}$

In the crystal structure of the complex, two complex molecules are linked through intermolecular hydrogen bonds of $\mathrm{O}-\mathrm{H} \cdots \mathrm{N}$ (Table 3), to form a dimer (Figure 4).

\section{4. Structure Description of the Zinc Complex}

Molecular structure of the zinc complex is shown in Figure 5. The $\mathrm{Zn}$ atom is in trigonal bipyramidal geometry, with the imino atom of the hydrazone ligand, and two chloride atoms located at the basal plane, and with the pyridine $\mathrm{N}$ and carbonyl $\mathrm{O}$ atoms located at the axial positions. The $\mathrm{Zn}$ atom deviates from the least-squares plane defined by the three basal donor atoms by $0.129(1) \AA$. The coordinate bond lengths in the complex are comparable to those observed in zinc(II) complexes with hydrazone ligands. ${ }^{14}$

In the crystal structure of the complex, the complex molecules are linked through intermolecular hydrogen bonds of $\mathrm{O}-\mathrm{H} \cdots \mathrm{O}$ (Table 3 ), to form chains along the $b$ axis (Figure 6).

\section{5. Biological Study}

The percent inhibition of the compounds at concentration of $100 \mu \mathrm{mol} \mathrm{L}^{-1}$ on Jack bean urease is summarized in Table 4. The hydrazones and the zinc complex have weak activity. However, the copper complex showed strong

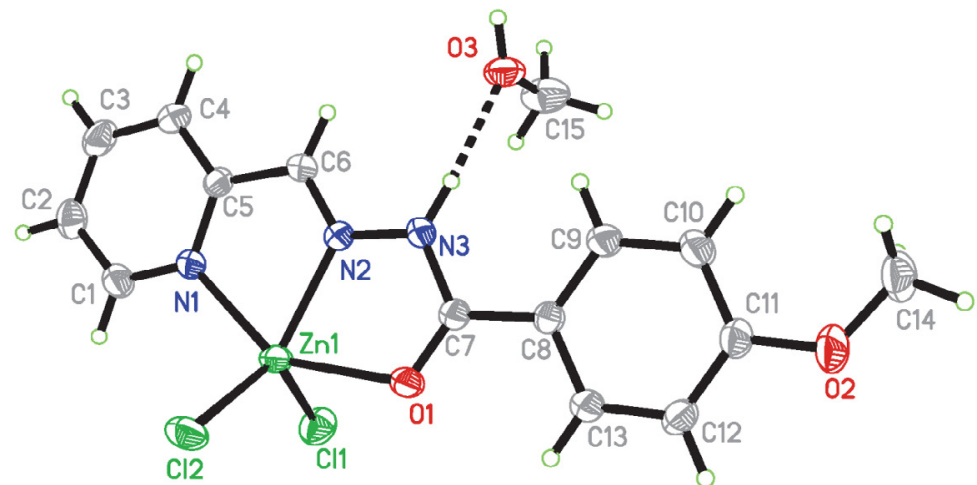

Figure 5. Molecular structure of 2, showing the atom-numbering scheme. Displacement ellipsoids for non-hydrogen atoms are drawn at $30 \%$ probability level.

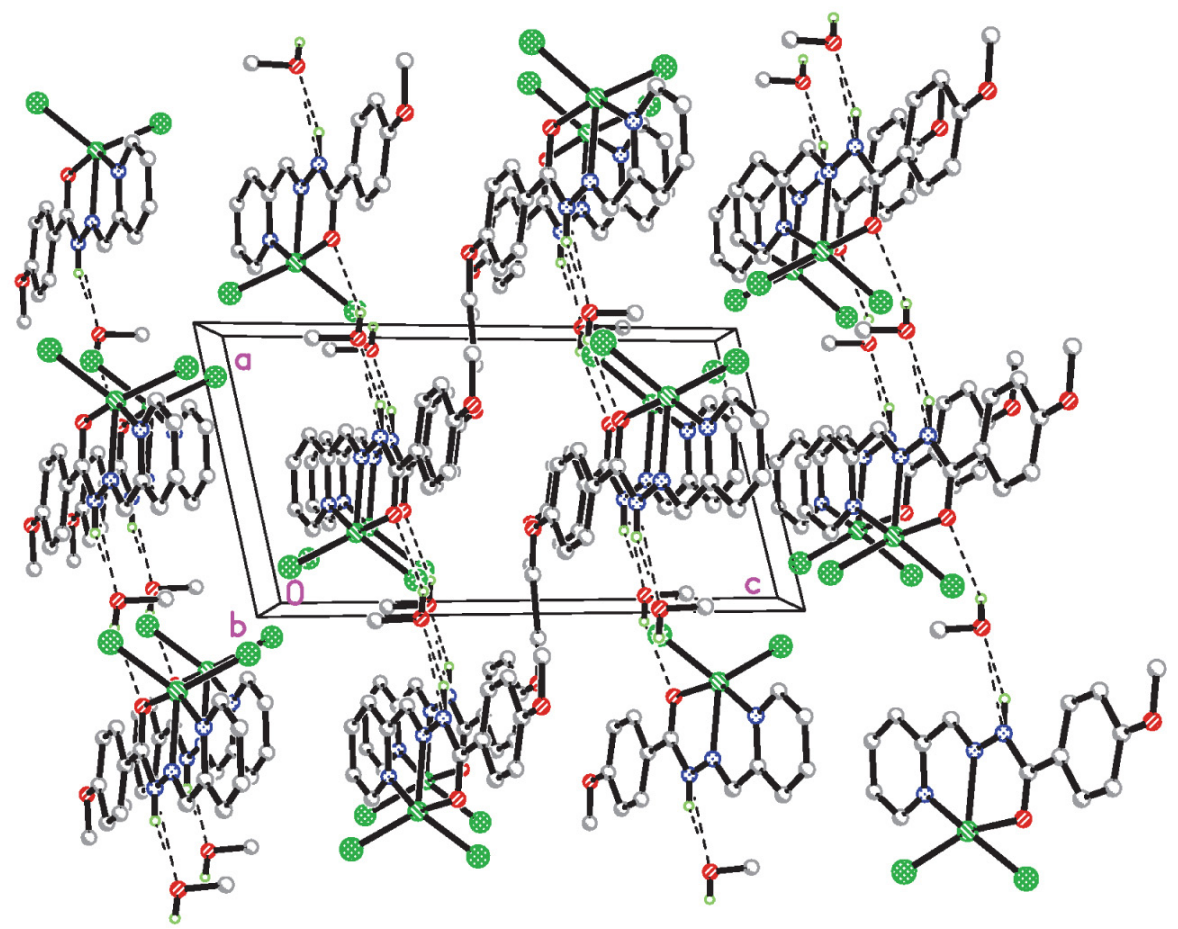

Figure 6. Molecular packing structure of 2 , viewed along the $b$ axis. Hydrogen bonds are shown as dashed lines. 
Table 4. Inhibition of urease by the tested materials

\begin{tabular}{|c|c|c|}
\hline Tested materials & $\begin{array}{c}\text { Percentage } \\
\text { Inhibition rate }\end{array}$ & $\begin{array}{c}\mathrm{IC}_{50} \\
\left(\mu \mathrm{mol} \mathrm{L}^{-1}\right)\end{array}$ \\
\hline $\mathrm{HL}^{1}$ & $32.7 \pm 2.1$ & $>100$ \\
\hline $\mathrm{HL}^{2}$ & $25.3 \pm 1.7$ & $>100$ \\
\hline 1 & $97.3 \pm 3.2$ & $1.4 \pm 0.8$ \\
\hline 2 & $45.0 \pm 2.6$ & $>100$ \\
\hline Copper perchlorate & $87.5 \pm 2.6$ & $8.8 \pm 1.4$ \\
\hline Zinc chloride & - & $>100$ \\
\hline Acetohydroxamic acid & $84.3 \pm 3.9$ & $37.2 \pm 4.0$ \\
\hline
\end{tabular}

\# The concentration of the tested material is $100 \mu \mathrm{mol} \mathrm{L}{ }^{-1}$.

urease inhibitory activity, with $\mathrm{IC}_{50}$ value of $1.4 \pm 0.8 \mu \mathrm{mol}$ $\mathrm{L}^{-1}$. As a comparison, acetohydroxamic acid (AHA) was used as a reference drug with the percent inhibition of 84.3 \pm 3.9 , and with $\mathrm{IC}_{50}$ value of $37.2 \pm 4.0 \mu \mathrm{mol} \mathrm{L}^{-1}$. Copper perchlorate can inhibit urease activity, with $\mathrm{IC}_{50}$ value of $8.8 \pm 1.4 \mu \mathrm{mol} \mathrm{L}{ }^{-1}$. Thus, the present copper complex is a good model for urease inhibition.

\section{Conclusion}

In summary, a new hydrazone compound 4-methoxy- $N^{\prime}$-(pyridin-2-ylmethylene)benzohydrazide was prepared and structurally characterized. With the hydrazones, a new copper(II) complex and a new zinc(II) complex were obtained. The complexes were characterized by physico-chemical method, and their structures were confirmed by single crystal X-ray determination. The copper complex has strong urease inhibitory activity, which deserves further study to explore novel and efficient urease inhibitors.

\section{Supplementary Data}

CCDC $1998916\left(\mathrm{HL}^{2}\right), 1547384$ (1) and 1813293 (2) contain the supplementary crystallographic data for this paper. These data can be obtained free of charge via http:// www.ccdc.cam.ac.uk/conts/retrieving.html, or from the Cambridge Crystallographic Data Centre, 12 Union Road, Cambridge CB2 1EZ, UK; fax: (+44) 1223-336-033; or e-mail: deposit@ccdc.cam.ac.uk. The IR and UV-Vis spectra are given in the supplementary information.

\section{References}

1. (a) T. Myrach, A. T. Zhu, C. P. Witte, J. Biol. Chem. 2017, 292, 14556-14565; DOI:10.1074/jbc.M117.780403

(b) T. Arshad, K. M. Khan, N. Rasool, U. Salar, S. Hussain, H. Asghar, M. Ashraf, A. Wadood, M. Riaz, S. Perveen, Bioorg. Chem. 2017, 72, 21-31; DOI:10.1016/j.bioorg.2017.03.007

(c) S. Yalcin, A. Basman, Food Chem. 2015, 169, 203-210.

DOI:10.1016/j.foodchem.2014.07.114
2. A. B. Mira, H. Cantarella, G. J. M. Souza-Netto, L. A. Moreira, M. Y. Kamogawa, R. Otto, Agr. Ecosyst. Environ. 2017, 248, 105-112. DOI:10.1016/j.agee.2017.07.032

3. R. J. Dempsey, N. A. Slaton, R. J. Norman, T. L. Roberts, Agron. J. 2017, 109, 363-377. DOI:10.2134/agronj2016.06.0374

4. (a) M. Taha, N. H. Ismail, S. Imran, A. Wadood, F. Rahim, M. Riaz, J. Bioorg. Med. Chem. 2015, 23, 7211-7218;

DOI:10.1016/j.bmc.2015.10.017

(b) Z. Amtul, R. A. Siddiqui, M. I. Choudhary, Curr. Med. Chem. 2002, 9, 1323-1348; DOI:10.2174/0929867023369853

(c) M. A. S. Aslam, S. U. Mahmood, M. Shahid, A. Saeed, J. Iqbal, Eur. J. Med. Chem. 2011, 46, 5473-5479;

DOI:10.1016/j.ejmech.2011.09.009

(d) A. Saeed, S. Zaib, A. Pervez, A. Mumtaz, M. Shahid, J. Iqbal, Med. Chem. Res. 2013, 22, 3653-3662;

DOI:10.1007/s00044-012-0376-4

(e) A. Saeed, M. S. Khan, H. Rafique, Bioorg. Chem. 2014, 52, 1-7. DOI:10.1016/j.bioorg.2013.10.001

5. (a) C. L. Jing, C. F. Wang, K. Yan, K. D. Zhao, G. H. Sheng, D. Qu, F. Niu, H. L. Zhu, Z. L. You, Bioorg. Med. Chem. 2016, 24, 270-276; DOI:10.1016/j.bmc.2015.12.013

(b) Y. Y. Zhu, C. F. Wang, K. Yan, K. D. Zhao, G. H. Sheng, Q. Q. G. Hu, L. Y. Zhang, Z. L. You, J. Coord. Chem. 2016, 69, 2493-2499; DOI:10.1080/00958972.2016.1186801

(c) Z. L. You, M. Y. Liu, C. F. Wang, G. H. Sheng, X. L. Zhao, D. Qu, F. Niu, RSC Advances 2016, 6, 16679-16690; DOI:10.1039/C6RA00500D

(d) D. Qu, F. Niu, X. L. Zhao, K. X. Yan, Y. T. Ye, J. Wang, M. Zhang, Z. L. You, Bioorg. Med. Chem. 2015, 23, 1944-1949; DOI:10.1016/j.bmc.2015.03.036

(e) X. F. Chen, C. F. Wang, S. Kong, C. Li, X. Zhou, C. Y. Zhang, G. H. Sheng, H. L. Zhu, J. Struct. Chem. 2017, 58, 797-803. DOI:10.1134/S0022476617040229

6. (a) Z. You, H. Yu, B. Zheng, C. Zhang, C. Lv, K. Li, L. Pan, Inorg. Chim. Acta 2018, 469, 44-50; DOI:10.1016/j.ica.2017.09.011 (b) S. H. Guo, T. R. Wang, J. J. Xin, Q. Q. G. Hu, S. F. Ren, G. H. Sheng, L. Pan, C. L. Zhang, K. Li, Z. L. You, J. Coord. Chem. 2017, 70, 3449-3458;

DOI:10.1080/00958972.2017.1390569

(c) J. Wang, D. Qu, J. X. Lei, Z. L. You, J. Coord. Chem. 2017, 70, 544-555; DOI:10.1080/00958972.2016.1262538

(d) L. Pan, C. F. Wang, K. Yan, K. D. Zhao, G. H. Sheng, H. L. Zhu, X. L. Zhao, D. Qu, F. Niu, Z. L. You, J. Inorg. Biochem. 2016, 159, 22-28. DOI:10.1016/j.jinorgbio.2016.02.017

7. Y. Tan, Acta Chim. Slov. 2019, 66, 1002-1009. DOI:10.17344/acsi.2019.5297

8. Bruker, SMART (Version 5.628) and SAINT (Version 6.02); Bruker AXS: Madison, Wisconsin, USA (1998).

9. G. M. Sheldrick, SADABS Program for Empirical Absorption Correction of Area Detector; University of Göttingen: Germany (1996).

10. G. M. Sheldrick, Acta Crystallogr. 2008, A64, 112-122. DOI:10.1107/S0108767307043930

11. W.-J. Mao, P.-C. Lv, L. Shi, H.-Q. Li, H.-L. Zhu, Bioorg. Med. Chem. 2009, 17, 7531-7536.

DOI:10.1016/j.bmc.2009.09.018 
12. (a) F. Zhi, N. Shao, Q. Wang, Y. Zhang, R. Wang, Y. Yang, J. Struct. Chem. 2013, 54, 148-154; DOI:10.1134/S0022476613010216

(b) X. L. Wang, Z. L. You, C. Wang, J. Chem. Crystallogr. 2011, 41, 621-624;

(c) J. Xu, T. Zhou, Z. Q. Xu, X. N. Gu, W. N. Wu, H. Chen, Y. Wang, L. Jia, T. F. Zhu, R. H. Chen, J. Mol. Struct. 2017, 1128, 448-454. DOI:10.1016/j.molstruc.2016.09.016
13. (a) K. Hu, G. M. Zhou, Z. Zhang, F. Y. Li, J. G. Li, F. P. Liang, RSC Advances 2016, 6, 36077-36084; DOI:10.1039/C6RA03478K

(b) Z. You, H. Yu, Z. Li, W. Zhai, Y. Jiang, A. Li, S. Guo, K. Li, C. Lv, C. Zhang, Inorg. Chim. Acta 2018, 480, 120-126. DOI:10.1016/j.ica.2018.05.020

14. H. Yu, S. Guo, J.-Y. Cheng, G. Jiang, Z. Li, W. Zhai, A. Li, Y. Jiang, Z. You, J. Coord. Chem. 2018, 71, 4164-4179. DOI:10.1080/00958972.2018.1533959

\section{Povzetek}

Sintetizirali smo nov bakrov(II) kompleks $\left[\mathrm{Cu}\left(\mathrm{L}^{1}\right)(\mathrm{NCS})\left(\mathrm{CH}_{3} \mathrm{OH}\right)\right]$ (1) in nove cinkov(II) kompleks [Zn$\left.\mathrm{Cl}_{2}\left(\mathrm{HL}^{2}\right)\right] \cdot \mathrm{CH}_{3} \mathrm{OH}(2) \mathrm{z}$ vezavo 4 -bromo- $N^{\prime}$-(piridin-2-ilmetilen)benzohidrazida $\left(\mathrm{HL}^{1}\right)$ in 4 -metoksi- $N^{\prime}$-(piridin-2ilmetilen)benzohidrazida $\left(\mathrm{HL}^{2}\right)$ ter ju okarakterizirali z elementno analizo, IR in UV-Vis spektroskopijo ter monokristalno rentgensko difrakcijo. Hidrazon $\mathrm{HL}^{1}$ se koordinira na $\mathrm{Cu}$ atom v enolatni obliki, medtem ko se hidrazon $\mathrm{HL}^{2}$ koordinira na $\mathrm{Zn}$ atom $\mathrm{v}$ karbonilni obliki. Rentgenska monokristalna analiza razkrije, da se hidrazona koordinirata na kovisnki atom preko piridinskega $\mathrm{N}$ atoma, imino $\mathrm{N}$ atoma in enolatnega/karbonilnega $\mathrm{O}$ atoma. $\mathrm{Cu}$ atom v kompleksu 1 je koordiniran kvadratno piramidalno, medtem ko je $\mathrm{Zn}$ atom v kompleksu 2 koordiniran trigonalno bipiramidalno. Proučili smo inhibitorni vpliv kompleksov na ureazo stročnice Canavalia ensiformis, ki kaže, da ima bakrov kompleks večjo aktivnost na ureazo.

Except when otherwise noted, articles in this journal are published under the terms and conditions of the Creative Commons Attribution 4.0 International License 